\title{
KECEMASAN BERBICARA DITINJAU DARI KONSEP DIRI DAN KECERDASAN EMOSIONAL
}

\author{
Kholisin \\ Yayasan Samudra Ilmu Semarang \\ Email: kholosin.okyes@gmail.com
}

\begin{abstract}
Abstrak
This study aims to test empirically the effect of self-concept of the anxiety of public speaking, the influence of emotional intelligence to the anxiety of public speaking, and the influence of self-concept and emotional intelligence to the anxiety of public speaking. Subjects were students of KKN force 64th 2015 Faculty of Da'wa and Communication UIN Walisongo Semarang in Waterford District are obtained using cluster random sampling. Data were analyzed using linear regression analysis simple and multiple linear regression. Moreover, the multiple linear regression analysis was used to test the effect of self-concept and emotional intelligence simultaneously to the anxiety of public speaking. The results showed: 1). Self-concept significantly influence the anxiety of public speaking, amounting to $51.9 \%$. $2)$. Emotional intelligence significantly influence the anxiety of public speaking, amounting to $34.9 \%$. 3). The concept of self and emotional intelligence influence simultaneously to the anxiety of public speaking, amounting to $60.4 \%$.
\end{abstract}

Penelitian ini merupakan penelitian kuantitatif yang bertujuan untuk menguji secara empiris pengaruh konsep diri terhadap kecemasan berbicara di depan umum, pengaruh kecerdasan emosional terhadap kecemasan berbicara di depan umum, dan pengaruh konsep diri dan kecerdasan emosional terhadap kecemasan berbicara di depan umum. Subyek penelitian adalah mahasiswa KKN angkatan ke-64 tahun 2015 Fakultas Dakwah dan Komunikasi UIN Walisongo Semarang di Kabupaten Temanggung secara cluster random ampling. Teknik analisis data menggunakan analisis regresi linier sederhana dan regresi linier berganda. Hasil penelitian ini menunjukkan: 1). Konsep diri berpengaruh secara signifikan terhadap kecemasan berbicara di depan umum, yaitu sebesar 51,9\%. 2). Kecerdasan emosional berpengaruh secara signifikan terhadap kecemasan berbicara di depan umum, yaitu sebesar 34,9\%. 3). Konsep diri dan kecerdasan emosional berpengaruh secara simultan terhadap kecemasan berbicara di depan umum, yaitu sebesar 60,4\%.

Keywords: anxiety of public speaking, self-concept, dan emotional intelligence 


\section{A. Latar Belakang}

Dakwah merupakan keharusan bagi tiap Muslim yang berakal dan berilmu. Hal itu sudah dicontohkan oleh Rasulullah SAW dan rasul-rasul sebelumnya dalam menjalankan tugasnya menyampaikan kerisalahan dan peraturan-peraturan Allah SWT. Zaidan (2001: 307) menyatakan bahwa dakwah adalah amanah yang diberikan Allah SWT kepada rasul-rasul-Nya (utusan-utusan-Nya) dan harus juga diteruskan perjuangan dakwah tersebut oleh umat-umatnya. Menurut Al Khayyath (1991: 79) dakwah merupakan kewajiban bagi umat muslim laki-laki dan muslim perempuan, kapanpun waktunya dan di manapun tempatnya. Hal senada diungkapkan Al Khauli (1929: 7) bahwa sebaik-baik manusia adalah orang yang mau menyampaikan dakwah mengajak kebaikan pada orang lain.

Kewajiban dakwah tersebut berkaitan dengan tujuan Allah SWT untuk menjadikan manusia mendapatkan kebahagiaan dunia dan akhirat (Mahfudz dalam Jumantoro, 2001: 17). Oleh karena itu, Allah SWT sudah memberikan kehormatan dan janji kepada manusia yang mau dan mampu mengemban amanah yakni berdakwah dengan menjadikan mereka sebagai sebaik-baiknya umat. Hal itu sebagaimana firman Allah SWT dalam QS. Ali Imran [3: 110], yang berbunyi:

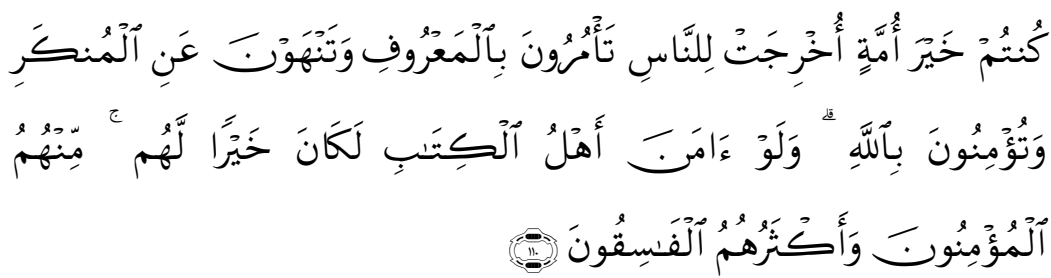

"Kamu adalah umat yang terbaik yang dilahirkan untuk manusia, menyuruh kepada yang ma'ruf, dan mencegah dari yang munkar, dan beriman kepada Allah. Sekiranya ahli kitab beriman, tentulah itu lebih baik bagi mereka.Di antara mereka ada yang beriman dan kebanyakan mereka adalah orang-orang yang fasik. (Departemen Agama RI, 1995: 182).

Sejalan dengan uraian di atas, cara atau metode yang dilakukan dalam berdakwah harus sesuai dengan sasaran dan tujuan ajakan tersebut ditujukan. Menurut Ismail dan Hotman (2011: 201) metode dakwah selalu merujuk pada firman Allah SWT dalam QS. Al-Nahl ayat 125. Ayat tersebut menjelaskan tiga cara atau metode dakwah. Pertama metode hikmah, 
yakni metode dakwah dengan menjelaskan doktrin-doktrin Islam serta realitas yang ada dengan argumentasi yang logis dan bahasa yang komunikatif. Kedua, metode mauidzah hasanah, yakni dakwah dengan menggunakan kata-kata yang masuk ke dalam hati, penuh kasih sayang, dan kelembutan. Ketiga, metode mujadalah, yakni dakwah dengan berdiskusi atau tukar pendapat yang dilakukan oleh dua belah pihak secara sinergis tanpa melahirkan permusuhan (Suparta dan Hefni, 2003: 7-20).

Dalam prakteknya, metode dakwah tersebut bisa efektif dengan kemampuan da'i dalam menyampaikan materi, ide, dan argumentasinya. Oleh karena itu, kemampuan berbicara seorang da'i di depan umum atau masyarakat mutlak diperlukan (dakwah bil lisan). Hal senada diungkapkan Ahmad dalam Sulthon (2003: 9) bahwa salah satu hal yang menjadikan dakwah mencapai tujuannya adalah kemampuan berbicara da'i dalam bertabligh, menyiarkan, dan menerangkan agama. Hal ini sebagaimana sabda Rasulullah SAW, "Barang siapa melihat suatu kemunkaran maka rubahlah dengan kekuasaannya, jika tidak mampu dengan kekuasaannya maka rubahlah dengan perkataannya (lisannya), jika tidak mampu dengan lisannya maka dengan hatinya, dan itu merupakan selemah-lemahnya iman." (An Nawawi, t.t.: 108).

Dalam rangka untuk mewujudkan kemampuan mahasiswa untuk berbicara di depan umum/masyarakat, berdakwah meneruskan amanah dan risalah Rasulullah SAW, dan mencetak kader da'i yang profesional maka Fakultas Dakwah dan Komunikasi UIN Walisongo Semarang mewajibkan Praktek Pengalaman Lapangan (PPL) Mayor untuk seluruh mahasiswanya. Sebagaimana diketahui bahwa semua mahasiswa laki-laki yang mengambil PPL Mayor diwajibkan untuk praktek khotbah di masjidmasjid di wilayah Semarang dan sekitarnya. Sementara itu, mahasiswi yang mengambil PPL Mayor diwajibkan untuk mengisi ceramah di majlis ta'lim tertentu di wilayah Semarang dan sekitarnya.

Berkaitan dengan pelaksanaan PPL Mayor tersebut, ternyata sebagian mahasiswa mengeluh dan gelisah ketika akan ceramah dan berbicara di depan umum. Sebagian mahasiswa merasa kehabisan katakata dan sulit untuk berbicara ketika dihadapkan dengan audiens. Studi Bukhori (2013: 2) menemukan bahwa dari 76 mahasiswa laki-laki Semester Gasal Tahun Akademik 2013/2014 yang mengambil PPL Mayor, tenyata hanya 29 mahasiswa (38,16\%) yang benar-benar menyampaikan khotbah. Fenomena tersebut tidak hanya terjadi pada pelaksanaan PPL Semester Gasal Tahun Akademik 2013/2014, akan tetapi selalu terjadi pada tiap pelaksanaan PPL. Bahkan pada tahun 2011 ada seorang mahasiswa PPL pingsan saat memberi kultum di Masjid Baitus Salam 
Ngaliyan. Selain itu, berdasarkan penuturan Ibu Ema Hidayati (Pembimbing PPL Mayor Fakultas Dakwah dan Komunikasi tahun 2014/2015, 2/4/2015) bahwa dari 158 mahasiswa yang mengambil PPL Mayor angkatan tahun 2014/2015 mayoritas tidak lancar ketika berbicara dan merasa kesulitan dalam menyampaikan materi dakwah.

Sebagaimana pada fakultas lainnya; di samping PPL Mayor yang merupakan kewajiban bagi seluruh mahasiswa Fakultas Dakwah dan Komunikasi, Kuliah Kerja Nyata (KKN) juga merupakan hal wajib yang harus diambil oleh mahasiswa. Persyaratan yang harus dipenuhi untuk bisa mengambil KKN adalah ketika para mahasiswa Dakwah dan Komunikasi sudah mengambil PPL Mayor. Persyaratan tersebut karena menyangkut pertimbangan bahwa: Pertama, KKN merupakan sebuah bentuk gambaran pengabdian langsung mahasiswa kepada masyarakat. ${ }^{1}$ Hal itu akan terwujud ketika mahasiswa mampu menyampaikan ide, gagasan, dan pendapatnya kepada masyarakat dengan kemampuan komunikasi mereka. Kedua, salah satu program KKN untuk mencapai visimisi pembangunan masyarakat desa adalah peningkatan pendidikan agama bagi masyarakat. Hal itu akan tercapai jika para mahasiswa mampu memberikan ceramah keagamaan dan pemahaman tentang agama pada masyarakat; baik melalui pengajian kepada masyarakat maupun melalui sekolah, madrasah, atau Taman Pendidikan Al Qur'an (TPA) pada anakanak. Dengan demikian, PPL Mayor tersebut minimal bisa dijadikan bekal dan pengalaman berbicara di depan umum dalam menyampaikan gagasan, ide, dan pendapat dalam pelaksanaan KKN.

Mengingat begitu pentingnya kemampuan berbicara mahasiswa dalam mencapai keberhasilan dakwah, salah satunya melalui pelaksanaan PPL Mayor dan KKN, maka persoalan kesulitan berbicara sebagaimana fenomena di atas harus dicarikan solusinya. Berdasarkan data kuisioner yang dibagikan pada sebagian mahasiswa KKN angkatan ke-64 UIN Walisongo yang berada di Kecamatan Tembarak, Tlogomulyo, dan Jumo pada tanggal 02/05/2015 - 04/05/2015, dari 86 mahasiswa yang menjawab kuisioner, 25 mahasiswa $(29,06 \%)$ diantaranya mengatakan belum berani menyampaikan sambutan atau ceramah di hadapan masyarakat tempat KKN. Dengan demikian, persoalan kesulitan berbicara

1Salah satu bukti nyata dari pengabdian mahasiswa KKN yang bersejarah adalah sekitar tahun 1988 di Dusun Kabunan, Kec. Bandung Gede, Kab. Temanggung. Di Desa tersebut terdapat masjid dan TPQ yang diberi nama "Baitul Huda". Nama masjid tersebut ternyata diambil dari salah satu nama mahasiswa KKN IAIN Walisongo Semarang yang bernama Sama'i Al Huda yang memberi banyak pengabdian pada masyarakat pada waktu itu (wawancara dengan tokoh masyarakat Kabunan pada tanggal 02/05/2015). 
di depan umum dialami oleh sebagian mahasiswa KKN angkatan ke-64 UIN Walisongo Semarang.

Salah satu kemungkinan besar yang menjadi penyebab kesulitan berbicara di depan umum tersebut adalah adanya kecemasan. Kecemasan tersebut muncul dan menghambat kemampuan berbicara seseorang. Menurut Hawari (1997: 63) seseorang yang mengalami kecemasan berbicara maka dia akan merasa panik. Perasaan panik tersebut dinamakan sebagai serangan panik (panic attack), yaitu suatu keadaan yang menjadikan seseorang mengalami kecemasan dan ketakutan yang luar biasa, seolah-olah yang bersangkutan sedang bergulat dengan maut. Namun, ketegangan dan ketidaktenangan ini kemudian muncul semakin sering dan memuncak, sampai pada gilirannya muncul sebagai serangan kecemasan yang mendadak (acute anxienty).

Kondisi tersebut di atas merupakan salah satu perwujudan dari kecemasan berbicara di depan umum², yakni suatu keadaan tidak nyaman yang dialami individu pada situasi berbicara di depan orang banyak, yang ditandai oleh reaksi fisik fisiologis dan psikologis (Dewi \& Andrianto, 2008: 9). Reaksi fisik fisiologis antara lain berupa ujung-ujung jari terasa dingin, detak jantung cepat, keringat bercucuran, kepala pusing, dan nafas sesak, sedangkan reaksi psikologis antara lain: merasa sangat takut, tidak dapat memusatkan perhatian, tidak berdaya/rendah diri, dan tidak tenang (Daradjat, 2001: 21). Bahkan menurut Semiun (2006: 321) orang yang mengalami kecemasan berbicara nantinya akan mengalami susah tidur,mudah marah, dan depresi.

Berdasarkan uraian di atas dapat ditarik pemahaman bahwa kecemasan berbicara merupakan persoalan yang serius yang harus dicarikan solusi atau jalan keluarnya. Jika masalah kecemasan berbicara di depan umum ini tidak mendapatkan jalan penyelesaian yang baik, tentunya akan berimbas pada ketegangan batin dan gangguan jiwa seseorang yang bersangkutan. Padahal, sudah diketahui bersama bahwa gangguan jiwa seseorang bisa ringan dan bisa berat, bisa mudah untuk diselesaikan dan bisa sulit untuk diselesaikan. Dengan demikian, penanganan terhadap

2 Perbedaan antara berbicara di depan umum dengan pembicaraan biasa adalah pada konteks pembicaraan biasa individu merasa aman untuk menyampaikan pikiranpikirannya. Bagian yang tidak dapat dipisahkan dari pembicaraan biasa adalah adanya proses memberi dan menerima, proses komunikasi dua arah (dialog).Berbeda dengan berbicara didepan umum, begitu individu mulai berbicara di depan umum, secara otomatis individu tersebut menjadi pemimpin dan memegang kendali penuh dari banyak orang. Proses komunikasi berubah menjadi satu arah (monolog). Individu yang takut berbicara di depan umum biasanya akan menghindarinya (Dewi dan Andrianto, 2006: 8). 
kecemasan berbicara merupakan hal yang penting untuk dikaji dan didiskusikan melalui penelitian-penelitian.

Menurut Studi Siska, Sudarjo, dan Purnamaningsih (2003: 68) kecemasan berbicara di depan umum berkaitan erat dengan kepercayaan diri. Studi Bukhori (2012: 3) menemukan bahwa kepercayaan diri seseorang memiliki pengaruh terhadap kecemasan berbicara di depan umum. Artinya, semakin tinggi kepercayaan diri seseorang maka semakin rendah kecemasan berbicara di depan umum. Sebaliknya, semakin rendah kepercayaan diri seseorang maka semakin tinggi kecemasan berbicara di depan umum. Sejalan dengan studi tersebut, Studi Sulistiyana (2011: 69) menemukan bahwa kepercayaan diri seseorang memberikan dampak positif terhadap kemampuan berbicara, mengurangi kecemasan berbicara di depan umum, memudahkan berinteraksi, dan penyesuaian sosial seseorang.

Hal lain yang berkaitan erat dengan kecemasan berbicara di depan umum adalah keterampilan komunikasi. Studi Ririn, Asmidir, dan Marjohan (2013: 275) menunjukkan bahwa keterampilan komunikasi seseorang berkorelasi negatif dengan kecemasan berbicara di depan umum. Artinya semakin tinggi keterampilan komunikasi maka semakin rendah kecemasan berbicara di depan umum. Sebaliknya, semakin rendah keterampilan komunikasinya maka semakin tinggi kecemasan berbicara di depan umum. Sejalan dengan studi tersebut, Studi Oktavia (2010: 19) menemukan bahwa kecemasan berbicara di depan umum dipengaruhi oleh kondisi psikis seseorang termasuk di dalamnya adalah berpikir negatif (negative thinking). Seseorang yang berpikir negatif maka akan mengalami kecemasan berbicara di depan umum. Hal senada diungkapkan Swann, Schneider, dan McClarty (2007: 91) bahwa pandangan positif terhadap diri seseorang akan mengurangi kecemasan seseorang.

Adapun Studi Ningsih (2003: 1) menemukan bahwa kecemasan berbicara di depan umum merupakan salah satu akibat kondisi psikis seseorang yang kurang baik, salah satunya adalah gagalnya seseorang menemukan konsep diri yang mantap. ${ }^{3}$ Sejalan dengan Studi Ningsih, Asendorpf, Banse, \& Mucke (2002: 380) menyatakan bahwa seseorang akan berperilaku sesuai dengan konsep diri yang dimiliki. Bila seseorang termasuk orang yang memiliki konsep diri tinggi maka ia akan mudah membuka diri dan berkomunikasi dengan orang lain. Tetapi berbeda

${ }^{3}$ Menurut Ningsih (2003: 1) seorang remaja yang menghadapi lingkungan dan norma yang baru, maka terkadang akan merasa gelisah dan cemas. Kegelisahan dan kecemasan ini merupakan salah satu bentuk kegagalannya menemukan konsep diri yang positif. 
dengan seseorang yang memiliki konsep diri rendah ia akan cenderung mengalami ketakutan dan kecemasan dalam berkomunikasi (communication apprehension) karena ia merasa tidak disenangi dan menganggap orang lain sebagai musuh (Rakhmat, 1986: 131).

Rogers dalam Hartono dan Soedarmadji (2012: 153) menyatakan bahwa konsep diri merupakan identitas diri yang terdiri dari dua hal, yaitu self riil (real-self) dan self ideal (ideal-self). Real-self merupakan gambaran sebenarnya tentang dirinya yang nyata, dan ideal-self merupakan apa yang menjadi kesukaan, harapan, atau yang idealisasi tentang dirinya. Jika realself kongruen atau sesuai dengan ideal-self maka seseorang dikatakan mempunyai konsep diri yang positif. Namun, jika keduanya tidak kongruen dan konsisten maka seseorang cenderung akan mengalami ketegangan dan kebingungan batin. Ketika hal tersebut eksis dan individu tadi tidak menyadarinya, maka dia rentan terhadap kecemasan (Pervin, Cervon, dan John, 2010: 181).

Menurut Goleman (2003: 11) kecerdasan emosional juga berkaitan dengan kecemasan dan pengendalian diri seseorang. Orang yang mempunyai kecerdasan emosional yang tinggi, maka ia memiliki sikap yang tenang dalam menghadapi sesuatu, tidak cemas, tidak khawatir, tidak mudah takut, dan tidak cepat bertindak melakukan sesuatu. Sejalan dengan Goleman, Studi Hidayanti (2007: 90) menemukan bahwa kecerdasan emosional berpengaruh terhadap efektivitas komunikasi intrepersonal seseorang. Kecerdasan emosional mempunyai pengaruh terhadap efektivitas komunikasi interpersonal seseorang. Dengan demikian, kecerdasan emosional menjadikan seseorang lebih bisa mengendalikan emosinya dan menahan diri, tabah dalam menghadapi kesulitan, dapat menyesuaikan diri dengan lingkungannya, dapat mengembangkan potensi, dan tidak cemas dalam mengatasi berbagai gangguan.

Studi Utami (2009: 28) menemukan bahwa seseorang akan merasa cemas bila dihadapkan dengan situasi yang berada di luar kendali, tidak menyenangkan, dan tidak kompromi dengan yang diinginkan. Namun, kecemasan tersebut bisa dikendalikan dengan kecerdasan emosional yang tinggi. Studi Melandy dan Aziza (2006: 2) menemukan bahwa keberhasilan seseorang tidak hanya didukung oleh keterampilan kerja yang bersifat fisik saja. Namun, keberhasilan seseorang harus dibarengi dengan kemampuan berkomunikasi, adaptasi, kreatifitas, ketahanan mental menghadapi kegagalan, motivasi, dan kepercayaan diri. Dengan demikian, hal yang mendukung seseorang bukan hanya aspek fisik saja, namun aspek psikis juga mempunyai peran yang begitu penting dalam mewujudkan 
keberhasilan seseorang termasuk di dalamnya adalah kecerdasan emosional.

Dalam rangka mewujudkan keberhasilan dakwah dan mencetak kader da'i dan da'iyah muda khususnya bagi mahasiswa Fakultas Dakwah dan Komunikasi UIN Walisongo Semarang dan umumnya bagi para muballigh maka pemahaman tentang kecemasan berbicara di depan umum sangat penting. Usaha yang dapat dilakukan untuk memperoleh pemahaman yang objektif tentang kecemasan berbicara di depan umum adalah dengan melakukan berbagai macam penelitian. Studi ini akan mengkaji pengaruh konsep diri dan kecerdasan emosional dengan kecemasan berbicara di depan umum pada mahasiswa KKN angkatan ke64 tahun 2015 Fakultas Dakwah dan Komunikasi UIN Walisongo Semarang dengan pertimbangan: Pertama, kecemasan berbicara di depan umum merupakan hal yang sangat penting untuk dicarikan solusinya. Bahkan studi Haryanti dan Tresniasari (2012: 1) menemukan bahwa di Barat, kecemasan berbicara di depan umum termasuk kategori fobia sosial yang menduduki gangguan kecemasan tertinggi dengan kisaran prevalensi 713\%. Kedua, mahasiswa merupakan generasi penerus dakwah Rasulullah SAW yang harus siap berdakwah kapanpun dan di manapun berada. Hal itu harus didukung dengan kemampuan mereka berinteraksi dengan masyarakat dan kemampuan berbicara di depan umum dalam menyampaikan dakwah.

Variabel independen yang dipilih dalam penelitian ini adalah konsep diri dan kecerdasan emosional karena diasumsikan dua variabel tersebut memiliki korelasi signifikan dengan kecemasan berbicara di depan umum. Selain itu, konsep diri dan kecerdasan emosional merupakan bagian dari potensi yang dimiliki manusia (Corey, 1990: 438). Potensi tersebut tentunya harus digunakan secara optimal untuk mencapai keberhasilan seseorang, salah satunya adalah keberhasilan berbicara di depan umum dalam rangka mengajak dan menyeru manusia dalam kebaikan (dakwah).

Wilson dalam Corey (1990: 440) menyatakan bahwa gangguan kecemasan dan depresi bisa ditangani secara efektif dengan pendekatan perilaku (behaviour). Sejalan dengan Wilson, Rahmat menyatakan bahwa (1986: 73) perilaku seseorang dipengaruhi oleh konsep diri dan kecerdasan emosional yang dimilikinya. Artinya, perilaku seseorang akan selaras dengan cara seseorang memandang dirinya sendiri(konsep diri). Apabila individu memandang dirinya sebagai orang yang tidak mempunyai cukup kemampuan untuk berbicara di depan umum, maka seluruh perilakunyaakan menunjukkan ketidakmampuannya untuk berbicara di depan umum. 
Bertolak dari argumen-argumen di atas, maka peneliti tertarik untuk meneliti tentang konsep diri, kecerdasan emosional, dan kecemasan berbicara di depan umum. Untuk itu, penelitian ini mengangkat judul PengaruhKonsep Diri dan Kecerdasan Emosional terhadap Kecemasan Berbicara di Depan Umum (Studi pada Mahasiswa KKN Angkatan ke-64 Tahun 2015 Fakultas Dakwah dan Komunikasi UIN Walisongo Semarang).

\section{B. Rumusan Masalah}

Berdasarkan latar belakang di atas maka rumusan masalah dalam penelitian ini adalah: 1) Adakah pengaruh konsep diri terhadap kecemasan berbicara di depan umum pada mahasiswa KKN angkatan ke-64 tahun 2015 Fakultas Dakwah dan Komunikasi? 2) Adakah pengaruh kecerdasan emosional terhadap kecemasan berbicara di depan umum pada mahasiswa mahasiswa KKN angkatan ke-64 tahun 2015 Fakultas Dakwah dan Komunikasi? 3) Adakah pengaruh konsep diri dan kecerdasan emosional secara simultan terhadap kecemasan berbicara di depan umum pada mahasiswa mahasiswa KKN angkatan ke-64 tahun 2015 Fakultas Dakwah dan Komunikasi?

\section{Metode Penelitian}

\section{Variabel Penelitian}

Variabel dalam penelitian ini adalah kecemasan berbicara di depan umum sebagai variabel dependen dan konsep diri dan kecerdasan emosional sebagai variabel independen.

\section{Subjek Penelitian}

Populasi dalam penelitian ini adalah mahasiswa KKN angkatan ke-64 tahun 2015 Fakultas Dakwah dan Komunikasi UIN Walisongo Semarang yang berjumlah 137 mahasiswa, dengan rincian mahasiswa Jurusan BPI 48 orang, mahasiswa Jurusan KPI 51 orang, dan mahasiswa Jurusan MD 38 orang (Kabag Akademik dan Kemahasiswaan Fakultas Dakwah dan Komunikasi 2015). Pengambilan sampel dilakukan secara cluster random sampling, yaitu sistem pengambilan sampel secara random terhadap kelompok-kelompok yang ada dalam populasi.

Alasan teknik tersebut digunakan adalah bahwa populasi dalam hal ini adalah mahasiswa KKN Fakultas Dakwah dan Komunikasi tersebar dalam beberapa posko KKN di 84 desa atau kelurahan dalam 6 kecamatan di Kabupaten Temanggung, yaitu Kecamatan Jumo, Bulu, Tembarak, 
Candiroto, Tlogomulyo, dan Wonoboyo. Langkah-langkah pengambilan sampel yaitu: Pertama, peneliti mengambil sampel lima kecamatan dari enam kecamatan yang menjadi lokasi KKN angkatan ke-64 secara random, yakni Tembarak, Tlogomulyo, Bulu, Jumo, dan Candiroto. Kedua, peneliti mengambil beberapa posko dari tiap-tiap kecamatan secara random.

\section{Instrumen Pengumpulan Data}

Instrumenpengumpulan data yang digunakan dalam penelitian ini adalah skala kecemasan berbicara di depan umum, skala konsep diri, dan skala kecerdasan emosional.

Untuk memilih item-item yang memiliki validitas dan reliabilitas yang baik, dalam penelitian ini dilakukan uji coba terlebih dahulu. Uji coba dilakukan terhadap mahasiswa KKN ke-64 UIN Walisongo Semarang angkatan tahun 2015/2016 dari Fakultas Ilmu Tarbiyah dan Keguruan, Syari'ah, Ekonomi dan Bisnis Islam, dan Ushuludin pada tanggal 21 April 2015 - 24 April 2015. Uji coba tersebut dilakukan pada mahasiswa KKN ke64 UIN Walisongo Semarang angkatan tahun 2015/2016 dari fakultas selain Fakultas Dakwah dan Komunikasi dengan pertimbangan bahwa diasumsikan mereka mempunyai ciri-ciri yang sama karena sama-sama mahasiswa semester akhir yang sudah banyak mengenyam pendidikan di bengku perkuliahan.

Seleksi item dilakukan dengan melakukan pengujian validitas terhadap semua item di setiap variabel. Pengujian dilakukan dengan menggunakan formulasi korelasi bivariate dari Pearson dan penghitungannya menggunakan bantuan program SPSS versi 16.0 (Wijaya, 2009: 110). Kriteria pemilihan validitas item menggunakan batasan $r-i x \geq 0,25$ (Azwar, 2012: 86).

Dalam penelitian ini estimasi reliabilitas dilakukan dengan menggunakan teknik Alpha dari Cronbach dan penghitungannya menggunakan bantuan program SPSS 16.0. Uji signifikansi dilakukan pada taraf $a=0,05$, instrumen dapat dikatakan reliabel jika nilai Alpha lebih berat dari pada $r$ tabel $(0,514)$. Estimasi reliabilitas dilakukan pada semua item yang valid di tiap-tiap variabel.

\section{Teknik Analisis Data}

Pengujian pengaruh variabel independen terhadap variabel dependen dalam penelitian ini dengan menggunakan teknik analisis regresi linier sederhana. Teknik analisis tersebut dilakukan dengan memanfaatkan program SPSS 16.0. Berdasarkan pengujian tersebut akan diketahui 
pengaruh konsep diri terhadap kecemasan berbicara di depan umum dan pengaruh kecerdasan emosional terhadap kecemasan berbicara di depan umum. Sementara itu, untuk menguji pengaruh konsep diri dan kecerdasan emosional terhadap kecemasan berbicara di depan umum maka penelitian ini menggunakan teknik analisis regresi linier berganda.

\section{Pembahasan}

\section{Kecemasan Berbicara di Depan Umum}

\section{a. Pengertian Kecemasan Berbicara di Depan Umum}

Kecemasan adalah suatu perasaan emosi yang kompleks dan kronis yang diiringi kekhawatiran dan ketakutan sebagai komponen utamanya, dicirikan sebagai bentuk kegelisahan dan gangguan-gangguan kejiwaan (Drever dalam Wibisono, 1985: 21). Hawari (1997: 62) menyatakan bahwa kecemasan merupakan bentuk kegelisahan dan gangguan kejiwaan seseorang yang biasanya ditandai dengan rasa panik. Menurut Ramaiah (2003: 6) kecemasan adalah hasil dari proses psikologi dan fisiologi dalam tubuh manusia. Hal senada diungkapkan Kartono (1986: 139) bahwa kecemasan adalah semacam kegelisahan, kekhawatiran, dan ketakutan terhadap sesuatu yang belum pasti terjadi.

Adapun pengertian berbicara menurut Rumanti (2005: 159) adalah penyampaian informasi yang dilakukan secara lisan melalui ucapan katakata.Tan (2010: 118) menyatakan bahwa berbicara adalah mengeluarkan dan menyusun kata-kata lisan secara teratur sehingga dapat dimengerti oleh lawan bicaranya. Tarigan (1981:15) juga menyatakan bahwa berbicara adalah kemampuan untuk mengucapkan kata-kata untuk mengekspresikan, serta menyampaikan pikiran, gagasan, dan perasaan. Sejalan dengan pengertian tersebut, Devitodalam Ririn, Asmidir, dan Marjohan (2014: 273-274) menyatakan bahwa berbicara di depan umum adalah suatu variasiseorang pembicara menghadapi pendengar dalam jumlah banyak yang bertujuan untuk mempublikasikan informasi dalam situasi tatap muka.

Dalam konteks dakwah, berbicara di depan umum merupakan hal yang sangat penting. Keduanya tidak dapat terpisah satu dan lainnya. Rasulullah SAW bersabda: "Barang siapa mengajak orang lain kepada petunjuk kebaikan maka baginya pahala seperti pahala-pahala dari orang yang mengikuti petunjuknya tanpa megurangi sedikitpun pahala pengikutnya. Barang siapa menyerukan jalan kesesatan pada orang lain maka baginya dosa seperti dosa-dosa kesesatan yang dilakukan 
pengikutnya tanpa mengurangi sedikitpun dosa-dosa pengikutnya (HR. Muslim) (An Naisanburi: t.t.: 167).

Berdasarkan uraian di atas dapat disimpulkan bahwa kecemasan berbicara di depan umum adalah emosi yang tidak menyenangkan, yang dapat menimbulkan ketakutan ketika harus berbicara, berceramah, atau menyampaikan pendapatnya di muka umum, baik secara individual maupun kelompok, yang ditunjukkan dengan adanya ketidakmampuan menyampaikan pesan secara sempurna (reaksi psikologis), fisiologis, dan reaksi perilaku secara umum.

\section{b. Aspek-Aspek Kecemasan Berbicara di Depan Umum}

Ramaiah (2003: 27) menyatakan bahwa terdapat gejala-gejala kecemasan, yakni: 1). Kejengkelan umum seperti rasa gugup, jengkel, tegang, rasa panik, tidak dapat tidur, danmudah merasa lelah. 2). Sakit kepala dengan ditandai tegangnya ototkhususnya di kepala, di daerah tengkuk, dan di tulang punggung.Rasa sakitnya mungkin terdapat di belakang kepala, di atas kepala, atau di sebelah depan. 3). Gemetaran di sekujur tubuh, khususnya di lengan dan tangan. 4). Aktivitas sistem otonomik yang meningkat, seperti pernafasan, pencernaan makanan, denyut jantung, keringat bercucuran (khususnya di telapak tangan), serta memanas dan memerahnya wajah, dan terkadang mulut menjadi makin kering atau air liur makin banyak di mulut.

Menurut Greenberger dan Padesky (2004: 210) aspek-aspek kecemasan ditandai dengan empat keadaan. 1). Reaksi fisik yaitu telapak tangan berkeringat, otot tegang, jantung berdegup kencang, pipi merona, dan pusing-pusing. 2). Reaksi perilaku yaitu menghindari, meninggalkan, dan menjauhi hal yang menjadikan cemas. 3). Reaksi pemikiran yaitu memikirkan bahaya secara berlebihan, menganggap diri sendiri tidak mampu mengatasi masalah, dan khawatir keburukan akan terjadi. 4). Suasana hati yaitu gugup, jengkel, dan panik. Sejalan dengan pendapat tersebut, Daradjat (1993: 27) menyatakan bahwa gejala-gejala kecemasan meliputi dua kondisi, yakni kondisi fisik meliputi: ujung-ujung jari terasa dingin, pukulan jantung cepat, keringat bercucuran, nafsu makan hilang, kepala pusing, nafas sesak, dan sebagainya. Kondisi psikologisantara lain: sangat takut, merasa akan ditimpa bahaya atau kecelakaan, tidak dapat memusatkan perhatian, tidak berdaya/rendah diri, dan sebagainya.

Berdasarkan uraian di atas dapat ditarik pemahaman bahwa aspekaspek kecemasan bisa dilihat dari beberapa sisi yang saling berkaitan, yaitu: sisi psikologis berkaitan dengan fisiologis. Misalnya, tegang, bingung, khawatir, sulit berkonsentrasi; mengakibatkan keadaan yang berhubungan 
dengan fisik seperti sukar tidur, jantung berdebar, keringat berlebihan, sering gemetar, perut mual, dan sebagainya. Begitu juga, sisi kognitif berkaitan dengan sisi perilaku. Misalnya, memikirkan sesuatu yang buruk akan terjadi mengakibatkan menghindar dan meninggalkan hal yang dianggap sebagai sebuah ancaman.

Dalam penelitian ini aspek-aspek kecemasan berbicara di depan umum adalah aspek-aspek kecemasan yang dikemukakan oleh Greenberger dan Padesky (2004: 210) yaitu: 1). Reaksi fisik. 2). Reaksi perilaku. 3). Reaksi pemikiran, dan 4). Suasana hati. Alasan aspek-aspek tersebut dipilih dengan pertimbangan bahwa aspek-aspek tersebut sudah mewakili aspek-aspek kecemasan menurut pendapat-pendapat lainnya dan mewakili kondisi kecemasan berbicara di depan umum.

\section{Konsep Diri}

\section{a. Pengertian Konsep Diri}

Menurut Shamir, House, dan Arthur (1993: 580) konsep diri merupakan susunan dari identitas diri, penilaian diri, dan penilaian sosial. Menurut Adler dalam Fudyartanta (2012: 221) bahwa konsep diri merupakan jembatan antara stimuli yang menerpa individu dan responsrespons yang diberikan kepada stimuli tersebut. Konsep diri memberi arti atau makna kehidupan, menciptakan tujuan dan sarana untuk mencapai tujuantersebut, dan mentransformasikan fakta-fakta yang ada menjadi sebuah kepribadian yang bersifat subjektif, dinamik, menyatu, personal, dan unik. Sementara itu, menurut Argyle (1967: 117) konsep diri hampir sama dengan citra diri yaitu acuan seseorang dalam menyadari, memahami, dan menerima tentang dirinya sendiri.

Jung dalam Pervin, Cervon, dan John (2010: 147) memandang bahwa konsep diri sama dengan psyche kepribadian secara keseluruhan. Namun, setelah Jung mengajukan konsep arketipe, ${ }^{4}$ maka ada salah satu arketipe yang mencerminkan perjuangan manusia ke arah kesatuan. Arketipe tersebut adalah diri (self). Diri (theself) atau konsep diri merupakan kekuatan bawah sadar seseorang yang berfungsi sebagai pusat pengorganisasi seluruh sistem psikologis seseorang. Atau dengan kata lain, diri adalah perjuangan ke arah kesatuan, integrasi, dan kebulatan dari semua kepribadian. Jika konsep diri berkembang positif maka seseorang akan merasa harmonis dengan dirinya dan lingkungannya. Namun, konsep

${ }^{4}$ Arketipe (archetypus) adalah suatu bentuk pikiran atau ide universal yang mengandung unsur emosi besar. Arketipe tersebut menciptakan gambaran-gambaran atau visi-visi, yang dalam kehidupan sadar berhubungan dengan aspek tertentu dari situasi. 
diri yang tidak berkembang secara baik menyebabkan kepribadian terpotong-potong dan menghalangi tercapainya kesehatan psikologis yang penuh (Fudyartanta, 2012: 24).

Horney dalam Koratno (2013: 154) menyatakan bahwa konsep diri adalah pemahaman dan pemaknaan tentang diri yang meliputi diri real (real-self) yaitu inti sejati dari seseorang yang mengandung potensi untuk pertumbuhan, kebahagiaan, kekuatan, kemauan, kapasitas, dan bakatbakat khusus untuk realisasi diri. Kemudian juga mencakup diri aktual (actual-self) yaitu diri yang ada secara objektif baik secara fisik maupun mental yang tidak tergantung pada persepsi-persepsi siapapun. Terakhir adalah diri ideal (ideal-self) yaitu diri seseorang yang berusaha untuk memecahkan konflik-konflik dengan melukiskan suatu gambaran diri.

Menurut Mappare (2006: 293) konsep diri adalah persepsi dan pemahaman seseorang tentang dirinya sendiri atau pemaknaan seseorang mengenai hal yang berkaitan dengan dirinya sendiri. Konsep diri tersebut mencakup diri sebagaimana dilihat oleh diri sendiri dan diri sebagaimana dilihat oleh orang lain. Hal senada diungkapkan McGraw (2001: 69) bahwa konsep diri merupakan kemampuan memahami diri dengan menyatukan keyakinan, fakta, opini, dan persepsi tentang diri seseorang dalam mengatasi berbagai persoalan hidupnya.

Dalam Islam konsep diri merupakan jalan untuk menuju keberhasilan dan kebaikan. Dengan memahami diri sendiri akan muncul sebuah kepercayaan diri yang mampu melihat manusia sebagai seorang manusia dan meyakini akan kebesaran Rabb-nya karena memiliki prinsip kepada Yang Esa, Tuhan pusat keyakinan dan kepercayaan dirinya. Hal ini sebagaimana diungkapkan oleh Al-Munajjid (2011: 47) bahwa ketika seseorang mengetahui dirinya sendiri dan mengimani bahwa Allah Maha Kuasa atas segala sesuatu, maka ia tidak bisa maju atau mundur satu langkahpun dari pengaturan-Nya. Ia akan menyungkurkan diri ke haribaan-Nya dan menyerahkan segala urusannya kepada-Nya setelah berusaha.

Berdasarkan uraian di atas, konsep diri adalah pemahaman seseorang terhadap dirinya sendiri sehingga seseorang akan mengerti makna dan tujuan kehidupan. Konsep diri seseorang terkadang positif jika terjadi keserasian antara pikiran dan perasaan, kongruen antara alam ide dan alam kenyataan. Namun, akan negatif jika terjadi sebaliknya. Konsep diri positif akan mampu menjadikan seseorang berkembang lebih baik dan lebih bermanfaat bagi dirinya, orang lain, dan lingkungan. 


\section{b. Aspek-Aspek Konsep Diri}

Aspek-aspek konsep diri menurut Mappare (2013: 293) meliputi konsep diri skolastik, sosial, fisik, dan religius. Burn (1993: 209) menyatakan bahwa konsep diri bersifat multi aspek yaitu meliputi empat aspek. Pertama, aspek fisiologis yaitu berkaitan dengan unsur-unsur fisik, seperti warna kulit, bentuk, berat atau tinggi badan, raut muka dan lainlain. Kedua, aspek psikologis meliputi kognisi (kecerdasan, minat dan bakat, kreativitas, kemampuan konsentrasi), afeksi (ketahanan, ketekunan, keuletan, dan motivasi), konasi (kecepatan dan ketelitian kerja, dan coping stress). Ketiga, aspek psiko-sosiologis yaitu berkaitan dengan hubungan terhadap lingkungan sosialnya. Keempat, aspek psikoetika dan moral yaitu kemampuan memahami dan melakukan perbuatan berdasarkan nilai-nilai etika dan moralitas.

Surna dan Pandeirot (2014: 151) menyatakan bahwa konsep diri ditandai dengan tiga aspek, yaitu: 1). Subjective self, yaitu pandangan, pikiran, dan perasaan mengenai diri sendiri baik aspek fisik maupun perilakunya. 2). Objective self atau social self, yaitu pendapat dan pandangan orang lain tentang diri individu. 3). Ideal self, yaitu konsep berpikir seseorang tentang dirinya yang mengarah pada cita-cita, keinginan, dan harapan seseorang sebagai tujuan utama kehidupan. Tujuan hidup ini menjadi penggerak dan motivasi dalam menjalani proses kehidupannya.

Dalam penelitian ini aspek yang digunakan adalah aspek-aspek yang dikemukakan oleh Surna dan Pandeirot. Alasan memilih aspek tersebut dikarenakan aspek-aspek yang dikemukakan Surna dan Pandeirot sederhana namun telah mewakili dari aspek-aspek yang lain.

\section{Kecerdasan Emosional}

\section{a. Pengertian Kecerdasan Emosional}

Kecerdasan emosional menurut Goleman (2003: 512) adalah kemampuan memahami perasaan diri sendiri dan kemampuan memahami perasaan orang lain, kemampuan memotivasi diri sendiri, dan kemampuan mengelola emosi yang baik pada diri sendiri dan dalam hubungannya dengan orang lain. Hal senada diungkapkan Weisinger dalam Masaong dan Tilomi (2011: 69) bahwa kecerdasan emosional adalah suatu instrumen kecerdasan untuk menyelesaikan masalah dengan orang lain, baik keluarga, teman, sahabat, dan relasi kerja.

Agustian (2001: 57) mengemukakan bahwa kecerdasan emosional merupakan kemampuan untuk mendengar bisikan emosional dan 
menjadikannya sebagai sumber informasi maha penting untuk memahami diri sendiri dan orang lain demi mencapai sebuah tujuan. Cooper dan Sawaf dalam Masaong dan Tilomi (2011: 69) menyatakan bahwa kecerdasan emosional adalah kemampuan merasakan, memahami, dan secara efektif menerapkan daya dan kepekaan emosi sebagai sumber energi, informasi, koneksi, dan pengaruh manusiawi. Hal senada diungkapkan Ciarrochi, Deane, \& Anderson (2002: 197) bahwa kecerdasan emosional merupakan prediktor terbaik yang menentukan keberhasilan seseorang.

Berdasarkan uraian di atas dapat ditarik pemahaman bahwa kecerdasan emosional merupakan kemampuan seseorang merasakan, memahami, memotivasi, dan mengelola emosi diri sehingga mendorong individu untuk mencapai potensi dan tujuan yang baik dan unik yang ada pada diri individu serta menggerakkan nilai-nilai aspirasi yang terpendam dalam berinteraksi kepada orang lain dan memecahkan masalah dalam interaksi sosial secara tepat dan akurat.

\section{b. Aspek-Aspek Kecerdasan Emosional}

Menurut Goleman (2003: 42) aspek-aspek kecerdasan emosional meliputi: 1). Kesadaran diri, yaitu mengetahui apa yang dirasakan pada suatu saat dan menggunakannya untuk memandu pengambilan keputusan diri sendiri. 2). Pengaturan diri, yaitu menangani emosi sehingga berdampak positif kepada pelaksanaan tugas; peka terhadap kata hati dan sanggup menunda kenikmatan sebelum tercapainya suatu sasaran. 3). Motivasi, yaitu kecenderungan emosi yang mengantar atau memudahkan pencapaian tujuan atau sasaran. 4). Empati yaitu kesadaran terhadap perasaan, kebutuhan, dan kepentingan orang lain. 5). Keterampilan sosial, yaitu keterampilan dalam menggugah tanggapan yang dikehendaki orang lain sehingga memiliki pengaruh positif terhadap orang lain, mempunyai komunikasi yang baik, mempunyai jiwa kepemimpinan, dan bisa mengelola konflik.

Sejalan dengan Goleman, Anthony (2004: 17) menyatakan bahwa kecerdasan emosional ditandai dengan lima hal. Kelima hal tersebut terkumpul dalam kata ARROW, yaitu: 1). Awareness (kesadaran diri), yaitu melihat diri sendiri dari sisi luar dari persepsi orang lain. 2). Restraint (pengekangan diri) yaitu keterampilan emosional seseorang dengan mengendalikan emosi yang merusak dan menjaga diri agar tidak maju terus dalam situasi yang memerlukan kesabaran. 3). Resilience (daya pemulihan) yaitu kemampuan untuk bertahan dan kembali tersenyum dan bangkit dari keterpurukan dan kekecewaan. 4). Others (emphaty) yaitu 
memahami dan merasakan yang dikehendaki orang lain dan memahami situasi. 5). Working with others (membina hubungan dengan orang lain).

Adapun Salovey, Mayer, Caruso, dan Sitarenios (2001: 234) menyatakan bahwa kecerdasan emosional memiliki empat aspek yaitu pengenalan emosi, pemahaman emosi, pengaturan emosi, dan penggunaan emosi. Agustian (2008: 123) menyatakan bahwa kecerdasan emosional mempunyai aspek-aspek sebagai berikut. 1). Rasa aman yaitu memiliki keyakinan penuh bahwa yang memiliki kemuliaan dan yang menghendaki kegagalan adalah Tuhan. Dengan demikian dengan rasa aman ini seseorang akan bersyukur ketika mendapat nikmat dan akan bersabar ketika diberikan ujian. 2). Kepercayaan diri, yaitu kemampuan untuk mengendalikan serta menjaga keyakinan diri untuk membuat perubahan. 3). Integritas yaitu bekerja secara total, sepenuh hati, dan dengan semangat yang tinggi. 4). Kebijaksanaan yaitu mampu mengambil keputusan dengan akurat dan tidak gegabah. 5). Mempunyai motivasi tinggi.

Berdasarkan pendapat di atas peneliti mengambil aspek-aspek kecerdasan emosional yang dikemukakan oleh Goleman, Anthony, dan Agustian yaitu: 1). Kesadaran diri. 2). Pengekangan diri. 3). Integritas. 4). Empati, dan 5). Membina hubungan dengan orang lain. Alasan aspekaspek kecerdasan emosional tersebut dipilih dengan pertimbangan bahwa aspek-aspek yang dikemukakan Goleman dan Anthony memiliki kesamaan, karena Anthony mengadopsi beberapa pendapat yang telah dikemukakan oleh Goleman. Sementara itu, aspek integritas yang dikemukakan Agustian juga dipilih dalam penelitian ini sebagai pengganti aspek motivasi yang dikemukakan Goleman dan Anthony. Aspek integritas mempunyai cakupan yang lebih luas daripada motivasi, karena motivasi masuk di dalam aspek integritas.

\section{E. Analisis dan Hasil Penelitian}

\section{Pengaruh Konsep Diri terhadap Kecemasan Berbicara di Depan Umum}

Untuk mengetahui pengaruh konsep diri terhadap kecemasan berbicara di depan umum maka dalam penelitian ini menggunakan teknik analisis regresi linier sederhana. Hasil analisis data mengenai pengaruh konsep diri terhadap kecemasan berbicara di depan umum menunjukkan koefisien pengaruh $\mathrm{F}$ regresi sebesar 69,08 lebih besar dari $\mathrm{F}$ tabel pada taraf signifikansi $0,05=2,54$ dan $\mathrm{F}$ tabel $0,01=3,30$ dengan nilai signifikan (pvalue) 0,00 . Oleh karena nilai signifikansi $\mathrm{F}$ regresi $>\mathrm{F}$ tabel pada taraf signifikansi $0,05=2,54$ dan $0,01=3,30$, dan nilai signifikan (pvalue) lebih 
kecil dari 0,05 maka dapat disimpulkan bahwa ada pengaruh konsep diri terhadap kecemasan berbicara di depan umum. Berdasar hasil tersebut maka dapat disimpulkan bahwa, semakin tinggi konsep diri, maka semakin rendah tingkat kecemasan berbicara di depan umum, sebaliknya semakin rendah konsep diri maka semakin tinggi tingkat kecemasan berbicara di depan umum.

Pengaruh variabel konsep diri terhadap variabel kecemasan berbicara di depan umum juga bisa diketahui dengan persamaan regresi dan $t$ hitung. Pengambilan keputusannya adalah dengan membandingan $t$ hitung dengan $t$ tabel. $T$ tabel $(63 ; 0,025)=1,998$. $T$ hitung 39,907 lebih besar dari $t$ tabel 1,998 berarti ada pengaruh konsep diri terhadap kecemasan berbicara di depan umum. Artinya semakin tinggi konsep diri maka semakin rendah kecemasan berbicara di depan umum. Sebaliknya, semakin rendah konsep diri maka semakin tinggi kecemasan berbicara di depan umum.

Adapun besarnya pengaruh konsep diri terhadap kecemasan berbicara di depan umum dapat dilihat dari nilai Adjusted R Square sebesar 0,519. Dengan demikian,konsep diri memiliki pengaruh terhadap kecemasan berbicara di depan umum sebesar 51,9\%. Adapun sisanya $48,1 \%$ dijelaskan oleh variabel-variabel lain di luar penelitian.

\section{Pengaruh Kecerdasan Emosional terhadap Kecemasan Berbicara di Depan Umum}

Hasil analisis denganmenggunakan teknik analisis regresi linier sederhana menunjukkan bahwa pengaruh kecerdasan emosional terhadap kecemasan berbicara di depan umum menghasilkan koefisien pengaruh $\mathrm{F}$ regresi sebesar 34,785 lebih besar dari $\mathrm{F}$ tabel pada taraf signifikansi 0,05 $=2,54$ dan $\mathrm{F}$ tabel $0,01=3,30$ dengan nilai signifikan (pvalue) 0,00 . Oleh karena nilai signifikansi $\mathrm{F}$ regresi $>\mathrm{F}$ tabel pada taraf signifikansi $0,05=$ 2,54 dan 0,01 =3,30, dan nilai signifikan (pvalue) lebih kecil dari 0,05 maka dapat disimpulkan bahwa ada pengaruh kecerdasan emosional terhadap kecemasan berbicara di depan umum. Berdasarkan hasil tersebut maka dapat disimpulkan bahwa, semakin tinggi kecerdasan emosional, maka semakin rendah tingkat kecemasan berbicara di depan umum, sebaliknya semakin rendah kecerdasan emosional maka semakin tinggi tingkat kecemasan berbicara di depan umum.

Pengaruh variabel kecerdasan emosional terhadap variabel kecemasan berbicara di depan umum juga bisa diketahui dengan persamaan regresi dan t hitung. Pengambilan keputusannya adalah dengan membandingan thitung dengan $\mathrm{t}$ tabel. $\mathrm{T}$ tabel $(63 ; 0,025)=1,998$. $\mathrm{T}$ hitung 
303,33 lebih besar dari t tabel 1,998 berarti ada pengaruh kecerdasan emosional terhadap kecemasan berbicara di depan umum. Artinya semakin tinggi kecerdasan emosional maka semakin rendah kecemasan berbicara di depan umum. Sebaliknya, semakin rendah kecerdasan emosional maka semakin tinggi kecemasan berbicara di depan umum.

Adapun besarnya pengaruh kecerdasan emosional terhadap kecemasan berbicara di depan umum dapat dilihat dari nilai Adjusted $\mathrm{R}$ Square yakni sebesar 0,349. Dengan demikian, kecerdasan emosional memiliki pengaruh terhadap kecemasan berbicara di depan umum sebesar $34,9 \%$. Adapun sisanya $65,1 \%$ dijelaskan oleh variabel-variabel lain di luar penelitian.

\section{Pengaruh Konsep Diri dan Kecerdasan Emosional terhadap Kecemasan Berbicara di Depan Umum}

Hasil analisis dengan menggunakan teknik analisis regresi linier berganda menunjukkan bahwa pengaruh konsep diri dan kecerdasan emosional terhadap kecemasan berbicara di depan umum menghasilkan koefisien pengaruh $\mathrm{F}$ regresi sebesar 48,952 lebih besar dari $\mathrm{F}$ tabel pada taraf signifikansi $0,05=2,54$ dan $\mathrm{F}$ tabel $0,01=3,30$ dengan nilai signifikan (pvalue) 0,00 . Oleh karena nilai signifikansi $\mathrm{F}$ regresi $>\mathrm{F}$ tabel pada taraf signifikansi $0,05=2,54$ dan $0,01=3,30$, dan nilai signifikan (pvalue) lebih kecil dari 0,05 maka dapat disimpulkan bahwa ada pengaruh konsep diri dan kecerdasan emosional secara simultan terhadap kecemasan berbicara di depan umum. Berdasarkan hasil tersebut maka dapat disimpulkan bahwa, semakin tinggi konsep diri dan kecerdasan emosional, maka semakin rendah tingkat kecemasan berbicara di depan umum, sebaliknya semakin rendah konsep diri dan kecerdasan emosional maka semakin tinggi tingkat kecemasan berbicara di depan umum.

Pengaruh variabel konsep diri dan kecerdasan emosional terhadap variabel kecemasan berbicara di depan umum juga bisa diketahui dengan persamaan regresi dan t hitung. Pengambilan keputusannya adalah dengan membandingkan antara $\mathrm{F}$ hitung dan $\mathrm{F}$ tabel. $\mathrm{F}$ hitung yakni $24,41>\mathrm{F}$ tabel $5 \%$ yaitu 3,418. Dengan demikian konsep diri dan kecerdasan emosional secara simultan berpengaruh terhadap kecemasan berbicara di depan umum.

Adapun besarnya pengaruh konsep diri dan kecerdasan emosional terhadap kecemasan berbicara di depan umum dapat dilihat dari nilai Adjusted R Square yakni sebesar 0,604. Dengan demikian, konsep diri dan kecerdasan emosional memiliki pengaruh terhadap kecemasan berbicara 
di depan umum sebesar 60,4\%. Adapun sisanya 39,6\% dijelaskan oleh variabel-variabel lain di luar penelitian.

Hasil penelitian ini sesuai dengan penelitian Olfson dkk. dalam Dewi dan Andrianto (2006: 8) yang menemukan bahwa salah satu hal yang menyebabkan kecemasan adalah berpikir negatif (negative thinking). Seseorang yang selalu berpikir negatif maka dia merasa panik, khawatir, dan merasa terancam dengan sesuatu yang belum tentu terjadi. Salah satu cara mengurangi kecemasan tersebut adalah senantiasa berpikir positif yang merupakan salah satu aktualisasi konsep diri positif seseorang. Menurut Rakhmat (1986: 131) berpikir positif (positivethinking) merupakan perwujudan seseorang dalam menilai dan menghargai dirinya, orang lain, dan lingkungannya (konsep diri positif). Sebaliknya, berpikir negatif (negativethinking) merupakan sikap hiperkritis terhadap dirinya, orang lain, dan lingkungannya (konsep diri negatif). Dengan sikap hiperkritis ini seseorang akan mengeluh, mencela, atau meremehkan dirinya, orang lain, atau lingkungan sekitarnya.

Sejalan dengan Olfson dkk., Anthony (2004: 17) menyatakan bahwa di samping berpikir positif merupakan perwujudan dari konsep diri, berpikir positif juga merupakan aktualisasi dari aspek kecerdasan emosional, yaitu membina hubungan dan kerjasama dengan orang lain (working with others). Seseorang yang memiliki kecerdasan emosional akan mampu membangun relasi, jaringan, dan partner dalam pekerjaannya; mampu menggerakkan, memengaruhi, mengkoordinasi, dan memberi arti kebaikan bagi kehidupan orang lain. Tentunya, berpikir positif tersebut merupakan elemen penting bagi terwujudnya hubungan dan kerjasama harmonis dengan orang lain. Dengan demikian, berpikir positif yang merupakan perwujudan konsep diri dan kecerdasan emosional merupakan hal penting dalam mengurangi kecemasan seseorang.

Berdasarkan uraian di atas dapat ditarik pemahaman bahwa konsep diri dan keceradasan emosional mempunyai korelasi yang signifikan dengan kecemasan berbicara di depan umum. Semakin tinggi konsep diri dan kecerdasan emosional seseorang maka semakin rendah kecemasan berbicara di depan umum. Sebaliknya, semakin rendah konsep diri dan kecerdasan emosional seseorang maka semakin tinggi kecemasan berbicara di depan umum.

Asserdof dalam Ririn, Asmidir, dan Marjohan (2013: 277) menyatakan bahwa orang yang memiliki kecemasan berbicara di depan umum memiliki skor yang rendah dalam keterampilan interpersonal dan interaksi sosial. Keterampilan interpersonal dan keterampilan interpersonal tersebut merupakan bagian dari konsep diri dan kecerdasan 
emosional. Studi Hidayanti (2007: 90) menemukan bahwa konsep diri dan kecerdasan emosional memiliki pengaruh sebesar 50,8\% terhadap efektivitas komunikasi interpersonal. Artinya, semakin tinggi konsep diri dan kecerdasan emosional seseorang maka semakin efektif komunikasi interpersonalnya. Sebaliknya, semakin rendah konsep diri dan kecerdasan emosional seseorang maka semakin rendah efektivitas komunikasi interpersonalnya.

Menurut Salovey dan Mayer (1990: 188) konsep diri dan kecerdasan emosional memengaruhi kehidupan sosial seseorang. Konsep diri dan kecerdasan emosional menjadikan seseorang memiliki flexible planning (rencana yang fleksibel atau banyak alternatif), creative thinking (berpikir kreatif), redirected attention (perhatian yang terarah), dan memiliki motivasi yang tinggi. Keempat hal tersebut bisa menjadikan seseorang memiliki pengaturan diri dan emosi (regulation of self and emotion) sehingga terhindar dari kecemasan berbicara di depan umum.

Berdasarkan uraian di atas dapat dipahami bahwa konsep diri dan kecerdasan emosional merupakan hal yang penting untuk mewujudkan keberhasilan komunikasi, interaksi sosial, dan mengurangi kecemasan berbicara di depan umum. Usaha untuk meningkatkan konsep diri dan kecerdasan emosional merupakan sebuah keniscayaan, karena konsep diri dan kecerdasan emosional bersifat dinamis. Pendidikan, pengalaman, dan lingkungan tempat berinteraksi memberi banyak kontribusi bagi terwujudnya peningkatan konsep diri dan kecerdasan emosional.

\section{F. Kesimpulan}

Kesimpulan yang diperoleh dari penelitian ini adalah : Konsep diri berpengaruh secara signifikan terhadap kecemasan berbicara di depan umum pada mahasiswa KKN ke-64 tahun 2015 Fakultas Dakwah dan Komunikasi UIN Walisongo Semarang. Artinya, semakin tinggi konsep diri maka semakin rendah kecemasan berbicara di depan umum. Sebaliknya, semakin rendah konsep diri maka semakin tinggi kecemasan berbicara di depan umum. Sumbangan pengaruh konsep diri terhadap kecemasan berbicara di depan umum sebesar 51,9\%, sedangkan sisanya 48,1\% dijelaskan oleh variabel-variabel lain di luar penelitian. Kecerdasan emosional berpengaruh signifikan terhadap kecemasan berbicara di depan umum pada mahasiswa KKN ke-64 tahun 2015 Fakultas Dakwah dan Komunikasi UIN Walisongo Semarang. Artinya, semakin tinggi kecerdasan emosional maka semakin rendah kecemasan berbicara di depan umum. Sebaliknya, semakin rendah kecerdasan emosional maka semakin tinggi 
kecemasan berbicara di depan umum. Sumbangan pengaruh kecerdasan emosional terhadap kecemasan berbicara di depan umum sebesar 34,9\%, sedangkan sisanya $65,1 \%$ dijelaskan oleh variabel-variabel lain di luar penelitian. Konsep diri dan kecerdasan emosional berpengaruh signifikan terhadap kecemasan berbicara di depan umum pada mahasiswa KKN ke-64 tahun 2015 Fakultas Dakwah dan Komunikasi UIN Walisongo Semarang. Artinya, semakin tinggi konsep diri dan kecerdasan emosional maka semakin rendah kecemasan berbicara di depan umum. Sebaliknya, semakin rendah konsep diri dan kecerdasan emosional maka semakin tinggi kecemasan berbicara di depan umum. Sumbangan pengaruh konsep diri dan kecerdasan emosional terhadap kecemasan berbicara di depan umum sebesar $60,4 \%$, sedangkan sisanya 39,6\% dijelaskan oleh variabel-variabel lain di luar penelitian.

Saran yang dapat dikemukakan dalam penelitian ini adalah: Untuk para dosen Fakultas Dakwah dan Komunikasi diharapkan bisa membantu mahasiswa meningkatkan konsep diri dan kecerdasan emosionalnya dengan memberi pemahaman pentingnya konsep diri dan kecerdasan emosional dalam mengurangi kecemasan berbicara di depan umum. Untuk mahasiswa Fakultas Dakwah dan Komunikasi khususnya dan mahasiswa fakultas lain pada umumnya diharapkan untuk meningkatkan konsep diri dan kecerdasan emosionalnya dalam menunjang keberhasilan komunikasi dan mengatasi kecemasan berbicara di depan umum.

Bagi peneliti selanjutnya yang tertarik untuk melakukan penelitian dengan topik tentang kecemasan berbicara di depan umum disarankan agar mempertimbangkan variabel-variabel lain seperti keterampilan komunikasi, kepercayaan diri, kemampuan adaptasi, dan lain-lain dengan harapan untuk bahan evaluasi demi terwujudnya komunikasi yang efektif dan terhindar dari kecemasan berbicara di depan umum. 


\section{DAFTAR PUSTAKA}

Adler, R.B., dan Rodman, G., 1991, Understanding Human Communication, Toronto: Holt Rinehart and Winston.

Agustian, A.G., 2001, Rahasia Sukses Membangun Kecerdasan Emosi dan Spiritual (Cetakan ke-6), Jakarta: Arga.

Al Khauli, Muhammad Abdul Aziz, 1929, Ishlahl Wa'dhi al-Dinniy, Al Qahirah: Dar al-Fikr.

Al Khayyath, Khalid bin Abdul Karim, 1991, al Uslub at-Tarbawiy li adda'wah ilallah fi al-Ashril Khadlir, Jeddah: Midanil Jami'ah.

Al Munajjid, Muhammad, 2011, TerapiKecemasan, Terj. AQWAM, dari Ilâjul Humum wa Syakâwa wa Hululun, Kertasura: Aqwam Media Profetika.

An Naisâburi, Muslim bin Hajjâj, 1991, Shahih Muslim, Bairut: Dar Ihya' Turats al-Arabi.

An-Nawâwi, Yahya Syarafudin, t.t., Syarh Arbain Nawâwiyah, Semarang: Toha Putra.

Anthony, M., 2004, Menjual dengan Kecerdasan Emosional, Terj. Alexander Sindoro, dari Selling with Emotional Intelligence, Batam: Interaksara.

Asendorpf, J.B., Rainer B., \& Daniel M., 2002, "Double Dissociation Between Implicit and Explicit Personality Self Concept: The Case of Shy Behaviour", Journal of Personality and Social Psychology, Vol. 83, No. 2, 380-394.

Azwar, S.,1996,Pengantar Psikologi Intelligensi, Yogyakarta: Pustaka Pelajar.

Ciarrochi, J., Frank P.D., \& Stephen A., 2002, "Emotional Intelligence Moderates the Relationship between Stress and Mental Health", Personality and Individual Differences, 32 (Desember), 197-209.

Daradjat, Z., 1993, Kesehatan Mental, Jakarta: Gunung Agung.

Dewi, A.P., dan Andriyanto, S., 2006, Hubungan antara Pola Pikir dengan Kecemasan Berbicara di Depan Umum pada Mahasiswa Fakultas Keguruan, (laporan Penelitian-tidak diterbitkan), Yogyakarta: UII. 
Greenberger, D., dan Padesky, 2004, Manajemen Pikiran: Metode Ampuh Menata Pikiran Untuk Mengatasi Depresi, Kemarahan, Kecemasan, dan Perasaan Merusak Lainnya, Terj. Bambang Margono, dari Mind Over Mood; Change How you Feel by Changing the way You Think, Bandung: PT Mizan Pustaka.

Goleman, D., 2003, Kecerdasan Emosi Untuk Mencapai Puncak Prestasi, Terj. Tri Kantono Widodo, dari Working With Emotional Intelligence, Jakarta: Gramedia Pustaka Utama.

Haryanti, L.P.S. dan Nia T., 2012, “Efektifitas Metode Terapi Ego State dalam Mengatasi Kecemasan Berbicara di Depan Publik pada Mahasiswa Fakultas Psikologi UIN Syarif Hidayatullah Jakarta", Jurnal Psikologi UIN Syarif Hidayatullah Jakarta, Vol. 14, No. 1 (April 2012), 32-40.

Hawari, D., 1997, Al Qur'an Ilmu Kedokteran Jiwa dan Kesehatan Jiwa, Yogyakarta: Dana Bhakti Prima Yasa.

Hidayanti, E., 2007, Pengaruh Kecerdasan Emosional dan Konsep Diri Terhadap Efektivitas Komunikasi Interpersonal (Studi Pada Perawat RSUD Tugurejo Semarang) (Tesis-tidak diterbitkan), Semarang: UIN Walisongo.

Jumantoro, T., 2001, Psikologi Dakwah; dengan Aspek-Aspek Kejiwaan yang Qur'ani, Wonosobo: Sinar Grafika Offset.

Kartono, K., 2000,Hygiene Mental, Mandar Maju.

Mappare, A., 2006, Kamus Istilah Konseling dan Terapi, Jakarta: PT Raja Grafindo Persada.

Masaong, Abd. Kadim dan Arfan A.T., 2011, Kepemimpinan Berbasis Multiple Intelegence; Sinergi Kecerdasan Intelektual, Emosional, dan Spiritual untuk Meraih Kesuksesan yang Gemilang, Bandung: Alfabeta.

McGraw, P.C., 2001, Self Matters, London: The Bath Press.

Melandi, R., dan Nurna A., 2006, Pengaruh Kecerdasan Emosional terhadap Tingkat Pemahaman Akuntansi (Penelitian-tidak diterbitkan), Bengkulu: Universitas Bengkulu.

Pervin, L., Daniel C., dan Olier P. J., 2010, Psikologi Kepribadian, Teori dan Penelitian Edisi 9, Terj. A. Anwar, K., Jakarta: Prenada Media Group.

Rakhmat,J., 1986,Psikologi Komunikasi, Bandung: Remaja Karya. 
Ramaiah, S., 2003, Kecemasan: Bagaimana mengatasi penyebabnya, Jakarta: Pustaka Populer Obor.

Ririn, Asmidir, dan Marjohan, 2014, Hubungan Keterampilan Komunikasi dengan Berbicara di Depan Umum, Jurnal Ilmiah Konseling UNP, Vol. 2, No.1 (Januari, 2013), 273-278.

Rumanti,2005, Dasar-Dasar Public Relations: Teori dan Praktik, Jakarta: PT. Grasindo.

Salovey, P., dan John D.M., 1990, "Emotional Intelligence", Journal of Psychology, 185-199.

Salovey, P., dan John D.M., 1993, "The Intelligence of Emotional Intelligence" Journal of American Psychological Association, Vol. 17, 433-442.

Salovey, P., John D.M., David R.C., dan Gill S., 2001, "Emotional Intelligence as a Standard Intelligence", Journal of American Psychological Association, Vol. 1 (Juli), No. 3, 232-242.

Semiun, Y., 2006, Kesehatan Mental 1, Yogyakarta: Kanisius.

Shamir, B., Robert J.H., \& Michael B.A., 1993, "The Motivational Effects of Charismatic, Leadership: A Self Concept Based Theory", Journal Organization Science, Vol. 4 (November), No. 4, 577-594.

Sulistiyana, R., 2011, Kepercayaan Diri dan Penyesuaian Sosial Remaja Korban Kekerasan Rumah Tangga; Studi Kasus di Desa Wonosari Kecamatan Ngaliyan, (Skripsi-tidak diterbitkan), Semarang: IAIN Walisongo.

Sulthon, M., 2003, Desain Ilmu Dakwah; Kajian Ontologis, Epistimologis, dan Aksiologis, Semarang: Pustaka Pelajar.

Surna, I.N., dan Olga D.P., 2014, Psikologi Pendidikan 1, Jakarta: Penerbit Erlangga.

Swann, W., Christine C.S., dan Katie L.M., 2007, "Do People Self Matter? Self Concept and Self Esteem in Everyday Life", American Pshycologist, Vol. 62 (Februari-Maret), No. 2, 84-94.

Utami, T.,2009, Hubungan Kecerdasan Emosional dengan Kecemasan Menghadapi Ujian Objektive Structural Clinical Assasment pada Mahasiswa Akademi Kebidanan Mitra Husada Karang Anyar (Karya Tulis Ilmiyah), Surakarta: Universitas Sebelas Maret. 
Wijaya, T., 2009, Analisis Data Penelitian Menggunakan SPSS, Yogyakarta: Universitas Atmajaya.

Wibisono, A., t.t., Hubungan Shalat dengan Kecemasan (Penelitian Ilmiah), Studia Press.

Zaidan, A.K., 2001, Ushul ad-Da'wah, Bairut: Muassasah ar-Risalah. 